\title{
Pola Distribusi Dan Stabilitas Harga Komoditas Cabai Merah Besar Dan Bawang Merah Di Pasar Wonomulyo Kecamatan Wonomulyo Kabupaten Polewali Mandar
}

\author{
Yusral* \\ Program Studi Agribisnis Fakultas Ilmu Pertanian Universitas Al Asyariah Mandar \\ yusra190@yahoo.com
}

\begin{abstract}
Abstrak
Penelitian ini di laksanakan selama 3 bulan yakni dari Bulan November 2016 sampai dengan Januari 2017 di Pasar Wonomulyo Kecamatan Wonomulyo Kabupaten Polewali Mandar. Penelitian ini bertujuan untuk mengetahui bagaimana pola distribusi dan stabilitas harga untuk komoditas cabe merah besar dan bawang merah di pasar wonomulyo kecamatan wonomulyo kabupaten polewali mandar. Metode yang digunakan dalam penelitian ini yakni metode secara sengaja atau proposive sampling dengan pedagang bawang merah dan cabai merah yang terdiri dari 13 orang Pedagang, 3 orang Pengepul, dan 3 orang Distributor yang ada di pasar Wonomulyo Kecamatan Wonomulyo, Kabupaten Polewali Mandar. Hasil penelitian menunjukkan bahwa pola distribusi yang ada di pasar wonomulyo dalam penelitian ini ada 3 saluran yaitu saluran I Distributor membeli barang di petani, dan langsung menyalurkannya kepada para Pengumpul yang ada di Pasar. Saluran II pengumpul membeli barang dagangan ke distributor dan menyalurkannya kepada para pedagang yang ada di pasar Wonomulyo, dan Saluran III Pedagang membeli barang dagangan ke pengumpul dan menyalurkannya kepada Konsumen yag datang untuk membeli keperluannya. Dari hasil penelitian pola distribusi Cabe Merah Besar dan Bawang Merah mulai bulan November 2016 sampai dengan bulan Januari 2017, dapat di ambil kesimpulan bahwa harga dari komoditas cabe merah besar dan bawang merah dalam penelitian ini tidak pernah stabil dikarenakan harganya yang selalu berubah-ubah dan tidak ada ketetapan harga dari setiap komoditas yang diperjual belikan.
\end{abstract}

Kata Kunci : Pola, Distribusi, Stabibilitas, Harga

\section{PENDAHULUAN}

Hortikultura pada dasarnya berasal dari bahasa Latin yaitu hortus yang berarti tanaman kebun dan cultura yang artinya budidaya. Jika digabungkan dari kedua suku kata tersebut, tanaman hortikultura adalah budidaya tanaman perkebunan. Namun pengertian tersebut belum menggambarkan hortikultura yang sebenarnya. Oleh karena itu kemudian hortikultura dalam perkembangannya digunakan secara lebih luas bukan hanya untuk budidaya di kebun. Jadi dapat diartikan, hortikultura merupakan salah satu cabang dari agronomi namun sedikit berbeda dengan agronomi, karena hortikultura memfokuskan pada budidaya tanaman buah, tanaman bunga atau tanaman hias, tanaman sayuran, dan tanaman obat-obatan. Ciri yang melekat pada tanaman hortikultura adalah produknya yang bersifat mudah rusak karena segar.

Komoditas hortikultura merupakan komoditas potensial yang mempunyai nilai ekonomi tinggi dan memiliki potensi untuk terus dikembangkan. Dari sisi penawaran atau produksi, luas wilayah Indonesia dengan keragaman agroklimatnya memungkinkan pengembangan berbagai jenis tanaman hortikultura, yang mencakup 323 jenis komoditas terdiri atas 60 jenis komoditas buah-buahan, 80 jenis komoditas sayuran, 66 jenis komoditas biofarmaka dan 117 jenis komoditas tanaman hias (Dirjen Holtikultura, 2008).

Salah satu komoditas hortikultura potensial untuk dikembangkan adalah komoditas cabai merah besar dan bawang merah. Cabai merah besar atau lombok (bahasa
Jawa) adalah sayuran buah semusim yang termasuk dalam anggota genus Capsicum yang banyak diperlukan oleh masyarakat sebagai penyedap rasa masakan (Sunaryono, 2003). Karena merupakan sayuran yang dikonsumsi setiap saat, maka cabai merah besar akan terus dibutuhkan dengan jumlah yang semakin meningkat seiring dengan pertumbuhan jumlah penduduk dan perekonomian nasional (Setiawati, 2005).

Bawang merah (Allium cepa L.) merupakan salah satu jenis komoditas yang mempunyai arti penting bagi masyarakat, baik dilihat dari nilai ekonomisnya dan permintaannya. Komoditas sayuran ini termasuk ke dalam kelompok rempah tidak bersubstitusi yang berfungsi sebagai bumbu penyedap makanan serta bahan obat tradisional (Deptan, 2005).

Adapun permasalahan untuk cabai merah besar dan bawang merah mengenai pola distribusi dan stabilitas harga di Wonomulyo masalah pertama adalah adanya perbedan harga yang tinggi antara harga ditingkat petani dan harga dipasar. Masalah kedua adalah adanya produk sayur import (termasuk bawang merah \& cabe merah besar) yang masuk ke pasar Wonomulyo dengan harga lebih murah, Produk yang masuk ke pasar Wonomulyo mutunya bagus, menyebabkan harga cabai merah besar dan bawang merah dalam daerah tertekan menurun. 


\section{Tujuan}

1. Untuk mengetahui pola distribusi pada komoditas cabai merah besar dan bawang merah di Kabupaten Polewali Mandar

2. Untuk mengetahui stabilitas harga pasar pada komoditas cabai merah besar dan bawang merah di Kabupaten Polewali Mandar

\section{METODE PENELITIAN}

Penelitian ini dilaksanakan di pasar Wonomulyo Kecamatan. Wonomulyo Kabupaten Polewali Mandar, yang berlangsung selama 3 (tiga) bulan yakni bulan November 2016 sampai dengan bulan Januari 2017.

\section{Penentuan Responden}

Penentuan sampel atau responden yang dilakukan dengan menggunakan metode Simple random sampling (acak sederhana). Sampel diambil secara acak dengan pedagang bawang merah dan cabai merah yang terdiri dari 128 orang Pedagang yang ada di pasar Wonomulyo Kecamatan Wonomulyo, Kabupaten Polewali Mandar. (Kantor Pasar Wonomulyo, 2015). Dengan berpatokan pada pendapat (Arikunto, $2002 ; 12$ ) bahwa jika populasi keseluruhan lebih dari 100, maka dapat di ambil 10\% - $15 \%$ dari jumlah populasi. Jadi jumlah sampel yang digunakan untuk pedagang bawang merah dan cabe merah berjumlah 13 orang, sedangkan untuk distributor sebanyak 3 orang dan pengumpul 3 orang berdasarkan hasil penelitian, pengambilan sampel untuk distributor dan pengumpul dilakukan secara sengaja ( proposive sampling).

\section{Tekhnik Pengumpulan Data}

Tekhnik pengumpulan data merupakan cara yang digunakan penelitian untuk mengumpulkan data dalam penelitian (Suharsimi Arikunto, 2006).

\section{Metode observasi}

Tekhnik ini dilakukan dengan mengadakan pengamatan langsung ke lokasi penelitian sehingga didapatkan gambaran/informasi yang jelas mengenai objek yang di teliti.

Wawancara digunakan sebagai tekhnik pengumpulan data apabila peneliti ingin melakukan studi pendahuluan untuk menemukan permasalahan yang harus di teliti, dan juga apabila peneliti ingin mengetahui hal-hal dari responden yang lebih mendalam dan jumlah respondennya sedikit/kecil (Sugiyono, 2012:137).

Metode dokumentasi adalah metode pengumpulan data dengan mencari data mengenai hal-hal atau variable yang berupa catatan, transkip, buku, dokumen, peraturan-peraturan, notulen rapat, agenda dan sebagainya (Suharsimi Arikunto, 2006:158).

Agrovital | Jurnal Ilmu Pertanian Universitas Al Asyariah

\section{Jenis Dan Sumber Data}

Data yang digunakan dalam penelitian ini terdiri dari

1. Data primer yaitu data yang dikumpulkan melalui observasi langsung dan wawancara langsung dengan responden dengan menggunakan kuesioner/ daftar pertanyaan

2. Data sekunder yaitu data yang dikumpulkan melalui berbagai sumber yang terkait dengan penelitian ini.

\section{Analisis Data}

Dalam penelitian ini, ada dua (2) metode analisis data yang digunakan adalah analisis deskriptif kualitatif dan analisis data Kuantitatif. Dalam penelitian kualitatif, pengumpulan data dilakukan pada natural setting (kondisi yang alamiah), sumber data primer dan teknik pengumpulan data lebih banyak pada observasi berperan serta, wawancara mendalam, dan dokumentasi.(Sugiono,2012)

Sedangkan metode kuantitatif dengan menggunakan analisis margin. Analisis margin pemasaran dilakukan untuk mengetahui perbedaan harga persatuan ditingkat produsen atau ditingkat konsumen yang terjadi pada rantai pemasaran (Sudiyono 2004). Data dianalisis berdasaran rumus sebagai berikut :

\section{Margin Pemasaran}

Rumus Margin Pemasaran seperti berikut ini :

Rumusnya : $\mathrm{M}=\mathrm{Hp}-\mathrm{Hb}$

Dimana : $\mathrm{M}=$ Margin pemasaran

$\mathrm{Hp}=$ Harga penjulan

$\mathrm{Hb}=$ Harga pembelian

Persentase margin

Persentase margin di tingkat distributor

Rumusnya : $\% \mathrm{M}=\mathrm{M} / \mathrm{HE}$ x $100 \% \quad \ldots . . . .$. (Sudiyono, 2004)

Dimana $\% \mathrm{M}=$ Persentase Margin dari semua saluran distribusi

$\mathrm{M}=$ Margin

$\mathrm{HE}=$ Harga penjualan

\section{Efesiensi Pemasaran}

Soekartawi (2002), menyatakan bahwa pemasaran akan semakin efisien apabila nilai efisiensi pemasaran semakin kecil. Soekartawi (2002), menyatakan bahwa efisiensi tataniaga dapat dihitung dengan menggunakan rumus sebagai berikut:

Rumusnya : $\quad E p s=\mathrm{Bp} / \mathrm{HE} \times 100 \%$

(Soekartawi, 2002)

Dimana Eps $=$ Efesiensi pemasaran

$\mathrm{Bp}=$ Harga pemasaran

$\mathrm{HE}=$ Harga Eceran

Keterangan : > $5 \%$ : maka dikatakan efesien

$<5 \%$ : maka dikatakan tidak

efesien 


\section{HASIL DAN PEMBAHASAN Umur Responden}

Aspek umur para pelaku usaha dagang turut menentukan sikapnya dalam pengambilan keputusan, termasuk dalam hal mengadopsi teknologi baru. Disamping itu, umur juga sangat menentukan kemajuan yang telah dicapai oleh seorang pedagang, sehingga umur merupakan salah satu faktor penting bagi pedagang dalam mengelolah usaha dagangannya ke arah yang lebih baik.

Pedagang yang berusia lanjut yang kemampuan fisiknya sudah menurun dan mengalami kesulitan dalam menerima perubahan dan inovasi baru dikarena selalu berpijak pada pengalaman masa lalunya. Berbeda halnya pada pedagang yang usia masih muda, disamping kemampuan fisiknya masih kuat, juga lebih kreatif sehingga lebih mudah dalam menerima inovasi baru dan cara- cara baru untuk mengembangkan usaha dagangnya.

Berdasarkan penjelasan diatas, dapat dilihat tingkat umur responden di pasar Wonomulyo Kecamatan Wonomulyo Kabupaten Polewali Mandar pada Tabel 1 berikut :

Pada Tabel 1 terlihat bahwa responden yang terbanyak jumlahnya yakni pada usia 40 - 44 tahun, sebanyak 6 jiwa, dengan jumlah keseluruhan responden sebanyak 19 jiwa dan persentasenya $(31,58 \%)$. Sedangkan yang palin sedikit yaitu pada usia 55 - 59 tahun, dengan jumlah jiwa 2, dari 19 keseluruhan jiwa, dan persentasenya (10,53\%).

Melihat kenyataan tersebut, maka dapat dikatakan bahwa responden yang ada di pasar Wonomulyo rata-rata berumur produktif antara 40 44 tahun. Hal ini sesuai dengan pendapat, bahwa umur 25 - 45 tahun seseorang menentukan prestasi kerja dan kinerja orang tersebut. Suratiyah (2006).

\section{Tingkat Pendidikan Responden}

Pendidikan adalah usaha sadar dan terencana untuk mewujudkan suasana belajar dan proses pembelajaran agar peserta didik secara aktif mengembangkan potensi dirinya untuk memiliki kekuatan spiritual keagamaan, pengendalian diri, kepribadian, kecerdasan, akhlak mulia, serta keterampilan yang diperlukan dirinya, masyarakat, bangsa dan negara (suparyono, 2006).

Adapun tingkat pendidikan responden yang ada di Pasar Wonomulyo, Kecamatan Wonomulyo Kabupaten Polewali Mandar dapat dilihat pada Tabel 2 dibawah ini:

Berdasarkan tabel 2 maka dapat dilihat bahwa tingkat pendidikan responden sudah mulai meningkat. Melihat dari tabel 2 diatas bahwa nilai pendidikan terbanyak ialah SLTA dan SLTP dengan jumlah responden sama-sama 8 jiwa, dan persentasenya $(42,105 \%)$. Sedangkan nilai pendidikan terendah yaitu SD dengan jumlah responden 3 jiwa, dan persentasenya $(15,79 \%)$

Maka dapat ditarik kesimpulan bahwa pendidikan responden sudah mulai meningkat meskipun masih sangat kurang dibanding dengan pedagang-pedagang yang ada di luar daerah. Keberhasilan suatu usaha tidak hanya ditunjang oleh pendidikan formal saja, akan tetapi pendidikan non formal juga berpengaruh terhadap keberhasilan usaha, seperti informasi atau pengetahuan yang diperoleh dari Pemerintah melalui media-media sosial misalnya surat kabar, radio, maupun mediamedia lainnya. Sejalan dengan pendapat (Tambunan, 2003) Rendahnya tingkat pendidikan dan keterbatasan teknologi modern merupakan dua faktor penyebab utama yang menyebabkan kemiskinan di sektor pertanian di Indonesia.

\section{Pengalaman Berwirausaha}

Elaine B Johnson (2007) menyatakan bahwa "pengalaman memunculkan potensi seseorang. Potensi penuh akan muncul bertahap seiring berjalannya waktu sebagai tanggapan terhadap bermacam-macam pengalaman".

Berdasarkan hasil penelitian tingkat pengalaman responden dalam mengelolah usaha dagangannya, diperoleh bahwa pengalaman responden yang paling banyak yaitu $20-24$ tahun, dengan jumlah responden 6 jiwa, dan persentasenya $(31,58 \%)$. Sedangkan pengalaman responden terendah ialah $30-34$ tahun, dengan jumlah responden 3 jiwa, dan nilai persentasenya $(15,79 \%)$. Rata-rata responden sudah sangat berpengalaman dalam bidang usaha tata niaga usaha ( perdagangan ). Menurut Soeharjo dan Patong (2006) bahwa pengalaman berusaha seseorang dapat dikatakan cukup berpengalaman apabila menggeluti bidang pekerjaannya selama 5 - 10 tahun, dengan kata lain 10 tahun keatas di kategorikan sangat berpengalaman, sedangkan 5 tahun kebawah masih kurang berpengalaman.

Dengan melihat pengalaman yang dimiliki oleh para pelaku usaha di pasar Wonomulyo Kecamatan Wonomulyo Kabupaten Polewali Mandar pada umumnya berpengalaman dalam melakukan usahanya.

\section{Tanggungan Keluarga}

Tanggungan keluarga adalah anggota keluarga yang harus di tanggung oleh responden. Semakin banyak anggota keluarga responden maka semakin banyak tenaga kerja yang tersedia, Tetapi dilain sisi tanggungan keluarga juga akan bertambah dan biaya hidup juga semakin tinggi. Untuk mengetahui tanggungan keluarga pada responden dalam penelitian ini diperoleh bahwa jumlah responden yang memiliki tanggungan pada $3-4$ jiwa itu 
berjumlah 12 orang responden dengan nilai persentase sebesar $63,16 \%$, dan jumlah responden yang memiliki tanggungan $5-6$ jiwa itu berjumlah 6 orang responden dengan nilai persentase 31,57\%, sedangkan yang memiliki tanggungan paling banyak yaitu $7-8$ jiwa hanya berjumlah 2 orang dengan nilai persentase sebesar $5,26 \%$.

Abdul Hamid a dkk (2012) menyatakan bahwa apabila terdapat kurang dari 3 orang jumlah anggota keluarga maka dikategorikan sebagai keluarga kecil, 4 - 5 orang dikategorikan keluarga sedang dan lebih dari 5 orang dikategorikan keluarga besar. Dengan melihat tingkat jumlah tanggungan keluarga responden pada pelaku usaha dengan mengutip pendapat Abdul Hamid a dkk (2012) dapat di jelaskan bahwa responden yang termaksud keluarga besar ada yang jumlah tanggungannya 5-6 dengan jumlah responden 6 jiwa dan nilai persentasenya $31,57 \%$ dan responde yang jumlah tanggungannya 7-8 tanggungan berjumlah 1 jiwa dengan nilai persentasenya sebesar 5,26\%. Sedangkan keluarga sedang $3-4$ dengan jumlah responden 12 keluarga dan jumah presentase sebesar $63,16 \%$.

\section{Analisis Data Bawang Merah dan Cabe Merah di Pasar Wonomulyo Kecamatan Wonomulyo Kabupaten Polewali Mandar}

Komuditas yang diperdagangkan berupa bahan pangan (sayur-sayuran) antara Kabupaten Enrekang dengan Kabupaten Polewali Mandar (Pasar Wonomulyo) atau dari Kabupaten lain ke pasar Wonomulyo dilakukan pada berbagai pelaku usaha dagang Penyuplai (Ditributor) ke pedagang Pengumpul kemudian disalurkan ke pedagangpedagang pengecer yang ada disekitar wilayah pasar Wonomulyo. Perkembangan alur distribusi barang dagangan di Kabupaten lain yang diantar ke pasar Wonomulyo mayoritas Komuditas bahan pangan (sayur-sayuran).

Berdasarkan hasil penelitian menunjukkan bahwa pendistribusian Cabai Merah Besar dan Bawang Merah yang pengirimannya melalui beberapa pedagang penyuplai (Distributor) dari Kabupaten Enrekang dengan tujuan ke pasar Wonomulyo. Gambaran ini dapat diperoleh secara nyata antara lain pada semua Responden yang ada di pasar Wonomulyo mulai dari pelaku usaha dagang Penyuplai (Distributor) yang dijadikan sampel dalam pendistribusian komuditas Cabai Merah Besar dan Bawang Merah asal Kabupaten Enrekang, dan disalurkan kepada pedagangan Pengumpul yang ada di pasar Wonomulyo kemudian disalurkan kepada pedagang-pedagang (Pengecer) yang ada di pasar Wonomulyo Kecamatan Wonomulyo Kabupaten Polewali Mandar.
Berdasarkan hasil penelitian yang dilakukan di pasar Wonomulyo dapat di lihat pada Gambar 3 seperti berikut :

hasil penelitian menunjukkan bahwa saluran I Distributor (pedagang penyuplai) itu datang setiap malam Rabu dan malam Mingggu. Setiap Distributor datang sekitar \pm jam 19:00 WIB, dan membawa barang dagangannya ke terminal dan langsung membongkar barangnya ke pedagang pengumpul. Menurut pernyataan dari setiap Responden bahwa setiap satu kali jalan mereka membawa Cabai Merah Besar sebanyak 10 kantong, dan dalam 1 kantong berisi Cabai Merah sebesar $10 \mathrm{Kg} / \mathrm{kantong}$. Sedangkan untuk bawang merah para distributor membawa 10 karung waring dengan berat dalam 1 karung waring sebesar $50 \mathrm{Kg} / \mathrm{karung}$.

Berdasarkan hasil penelitian menunjukkan bahwa Saluran II Pedagang Pengumpul akan menyalurkan barang dagangannya mulai pada jam 00:00 sampai pada pagi hari kepada para pedagangpedagang yang ada di pasar Wonomulyo. Hal ini dilakukan pada pasar subuh di daerah Terminal Wonomulyo. Sedangkan untuk Saluran III para pedagang-pedagang yang ada di sekitar Wonomulyo menyalurkan barang dagangannya kepada konsumen yang datang untuk membeli keperluannya atau bahkan sebaliknya para konsumen yang datang kepada para pedagang untuk membeli.

Dari pejelasan diatas, dapat di lihat jumlah Cabai Merah Besar dan Bawang Merah yang tersalurkan dari data yang diperoleh bahwa permintaan barang dagangan selama penelitian dilakukan mulai bulan November 2016 sampai dengan bulan Januari 2017 dari ke 3 (tiga) pelaku usaha Distributor barang dari Kabupaten Enrekang ke pasar Wonomulyo untuk komoditas Bawang Merah lebih tinggi yaitu $32.400 \mathrm{Kg}$ (36 Ton) dari pada Cabai Merah yang hanya mencapai $8.100 \mathrm{Kg}$.

Hal ini disebabkan karena pasokan barang dagangan untuk komoditas Bawang Merah lebih banyak dari Enrekan karena Kabupaten Enrekang salah satu penghasil Bawang Merah terbesar untuk Wilayah Sulawesi Selatan. Sedangkan untuk Komoditas cabai merah besar hanya beberapa petani saja yang melakukan tanam cabai merah besar. Untuk pasokan terbesar cabai merah besar di daerah pasar Wonomulyo menurut keterangan dari pengurus pasar Wonomulyo itu banyak datang dari daerah Pinrang dan Sulawesi Utara.

\section{Stabilitas Harga Cabe Merah Besar dan Bawang Merah}

Analisis margin pemasaran dilakukan untuk mengetahui perbedaan harga persatuan ditingkat produsen atau ditingkat konsumen yang terjadi pada rantai pemasaran (Sudiyono 2004). 


\section{Margin Pemasaran Cabe Merah Besar dan Bawang Merah di Tingkat Distributor}

Berdasarkan hasil penelitian di lapangan pada setiap responden yang ada di pasar Wonomulyo pada bulan November 2016 sampai dengan bulan Januari 2017, diperoleh tingkat nilai rata-rata harga pembelian untuk komoditas cabe merah besar nilai rata-rata pembelian selama penelitian dilakukan yaitu Rp. 22.333,- dan nilai harga penjualannya yaitu $\mathrm{Rp}$. 24.333,- sehingga nilai marginnya ialah Rp.2.000,Sedangkan komoditas bawang merah ialah $\mathrm{Rp}$. 31.667,- dan nilai harga penjualannya yaitu $\mathrm{Rp}$. 33.667,- dengan nilai rata-rata margin dari harga penjualan dibagi dengan harga pembelian yaitu $\mathrm{Rp}$. $2.000,-$

Jadi nilai rata-rata margin dari setiap komoditas pada bulan November 2016 sampai dengan bulan Januari 2017 yaitu untuk komoditas cabe merah besar yaitu Rp. 2.000,- sedangkan untuk bawang merah Rp. 2.000,-.

Margin Pemasaran Cabe Merah Besar dan Bawang Merah di Tingkat Pengumpul

Berdasarkan hasil dari penelitian dilapangan terhadap responden untuk Margin Pemasaran pada komoditas cabe merah besar dan bawang merah pada bulan November 2016 sampai dengan bulan Januari 2017 diperoleh tingkat nilai rata-rata harga pembelian untuk komoditas cabe merah besar nilai rata-rata pembelian dari semua pelaku usaha yaitu Rp. 24.333,- dan nilai harga penjualannya yaitu 27.333,sehingga nilai marginnya ialah Rp. 3.000,-. Sedangkan pada komoditas bawang merah ialah Rp. 33.667,- dan nilai harga penjualannya yaitu Rp. 36.000 ,- dengan nilai rata-rata margin dari harga penjualan dibagi dengan harga pembelian yaitu $\mathrm{Rp}$. $2.333,-$.

Jadi nilai rata-rata margin dari setiap komoditas dari semua pelaku usaha pada bulan November 2016 sampai dengan bulan Januari 2017 yaitu untuk cabe merah besar yaitu Rp. 3.000,-. sedangkan komoditas bawang merah Rp. 2.333,-.

\section{Margin Pemasaran Cabe Merah Besar dan Bawang Merah di Tingkat Pedagang}

Berdasarkan hasil dari penelitian dilapangan terhadap responden untuk Margin Pemasaran pada komoditas bawang merah dan cabe merah besar pada bulan Januari 2017 diperoleh tingkat nilai rata-rata harga pembelian untuk komoditas cabe merah besar nilai rata-rata pembelian dari semua pelaku usaha yaitu Rp.27.333,- dan nilai harga penjualannya yaitu 31.333 ,- sehingga nilai marginnya ialah Rp. 4.000,-. sedangkan untuk komoditas bawang merah ialah $\mathrm{Rp}$. 36.000 ,- dan nilai harga penjualannya yaitu $\mathrm{Rp}$. 39.282 ,- dengan nilai rata-rata margin dari harga penjualan dibagi dengan harga pembelian yaitu $\mathrm{Rp}$. $3.282,-$

Jadi nilai rata-rata margin dari setiap komoditas dari semua pelaku usaha pada bulan Januari 2017 yaitu untuk cabe merah besar yaitu Rp.4.000,- sedangkan untuk komoditas bawang merah Rp. 3.282,-.

\section{Persentase (\%) Margin Pemasaran}

Persentase Margin dalam suatu kegiatan pemasaran dapat dijadikan dasar atau tolak ukur efisiensi pemasaran. Semakin tinggi tingkat persentase yang diterima petani maka dikatakan semakin efisien kegiatan pemasaran yang dilakukan dan sebaliknya semakin rendah tingkat pesentase yang diterima petani, maka akan semakin rendah pula tingkat efisiensi dari suatu pemasaran

Berdasarkan hasil penelitian dilapangan terhadap responden yang ada di pasar Wonomulyo, maka dapat dilihat Persentase Margin untuk Setiap komoditas pada bulan November 2016 sampai dengan bulan Januari 2017 dapat dilihat pada pada tabel 9 berikut :

Berdsarkan Tabel 9 menunjukkan bahwa nilai rata-rata Persentase (\%) margin pemasaran pada bulan November 2016 untuk Komoditas cabe merah besar yaitu $11 \%$. sedangkan untuk komoditas bawang merah yaitu $7 \%$.

\section{Efisiensi Pemasaran}

Efisiensi harga adalah menyangkut harga komoditas bawang merah dan cabe merah besar mulai dari distributor sampai Kepada pedagang akhir pada saluran pemasaran. Efisiensi harga ditentukan oleh, margin pemasaran, dan total harga pemasaran.

Efisiensi pemasaran bawang merah dan cabe merah besar pada bulan November sampai bulan Januari 2017 yaitu, berdasarkan penjelasan tentang Efisiensi pemasaran

Nilai rata-rata $>5 \%$ maka dikatakan Efisien

Efisien

$$
<5 \% \text { maka dikatakan tidak }
$$

Nilai rata-rata efisiensi pemasaran di tingkat Distributor untuk cabe merah besar $78 \%$. sedangkan Untuk bawang Merah yaitu $86 \%$, nilai rata-rata efisiensi pemasaran di tingkat pengumpul pada komoditas cabe merah besar yaitu $87 \%$ sedangkan untuk komoditas bawang merah yaitu 92\%,. Dan untuk nilai rata-rata efisiensi pemasaran di tingkat pedagang pada untuk komoditas cabe merah besar yaitu $100 \%$. sedangkan komoditas bawang merah yaitu $100 \%$.

Dari penjelasan untuk Tabel 8 , dapat dikatakan bahwa dari semua pelaku usaha mulai dari tingkat Distributor, Pengumpul, dan Pedagang pada bulan November 2016 sampai dengan bulan Januari 
2017 bernilai efisien. Hal ini dikatakan efisien karena dari semua hasil nilai rata-rata efisiensi pemasaran mulai bulan November 2016 sampai dengan bulan Januari 2017, lebih besar dari $5 \%$ sesuai dengan keterangan ketentuan rumus Efisiensi Pemasaran

\section{Harga Patokan Pemerintah Cabe Merah Besar dan Bawang Merah}

Pemerintah menetapkan harga acuan pembelian terhadap tujuh komoditas pangan. Tujuannya untuk menjamin ketersediaan, stabilitas dan kepastian harga pangan, baik di tingkat petani maupun konsumen.

Berikut ini rincian harga acuan penjualan pada komoditas Cabe Merah Besar dan Bawang Merah di tingkat konsumen, yang mulai berlaku pada bulan Oktober 2016 hingga empat bulan ke depan :

1. Harga bawang merah Rp $32.000 / \mathrm{kg}$.

2. Harga cabai merah besar Rp $28.500 / \mathrm{kg}$

\section{Stabilitas Harga Cabe Merah Besar dan Bawang Merah}

Berdasarkan pembahasan tentang ketetapan harga patokan setiap Komoditas dalam penelitian ini cabe merah besar dan bawang merah dapat dilihat Stabilitas harga pada komoditas bawang merah dan cabe merah besar pada Tabel 11 berikut ini :

Berdasarkan Tabel 11 dapat di lihat bahwa nilai rata-rata harga pejualan bawang merah untuk distributor yaitu Rp. 33.667,- Pengumpul yaitu Rp. 36.000,- dan pedagang yaitu Rp. 39.282,- bulan November 2016 sampai dengan bulan Januari 2017. Sedangkan untuk komoditas cabe merah besar yaitu dari Distributor yaitu Rp. 24.333,- Pengumpul yaitu Rp.27.333,- Pedagang yaitu Rp. 31.333,-- pada bulan November 2016 sampai dengan bulan Januari 2017.

Pada stabilitas harga, dapat di lihat bahwa harga dari setiap pola distribusi mulai bulan November 2016 sampai dengan bulan Januari 2017 pada komoditas bawang merah dan cabe merah besar di pasar Wonomulyo kecamatan Wonomulyo Kabupaten Polewali Mandar menunjukkan bahwa tidak stabilnya harga mulai dari tingkat Distributor, Pengumpul, dan Pedagang yang selalu berubah-ubah harga penjualannya. Harga dari setiap komoditas, kadang harga jualnya tinggi dan kadang pula turun. Hal ini disebabkan karna para pedagang menyesuaikan harga pembeliannya dengan harga yang harus dijualkan agar tidak merugi.

\section{KESIMPULAN}

Dari hasil analisis yang telah diolah mengenai Pola Distribusi dan Stabilitas Harga Cabe Merah Besar dan Bawang Merah di Pasar Wonomulyo, Kecamatan Wonomulyo, Kabupaten Polewali Mandar, bahwa:
1. Pola Distribusi Bawang Merah dan Cabe Merah Besar di Pasar Wonomulyo yaitu ada 3. Margin Pemasaran ditingkat Distributor pada komoditas Bawang Merah yaitu sebesar Rp.2.000,- dan Margin untuk Cabe Merah besar yaitu Rp.2.000,-. Sedangkan margin Pemasaran di tingkat pengumpul untuk komoditas Bawang Merah yaitu sebesar Rp.2.333,- dan Margin untuk Cabe Merah yaitu Rp.3.000,-. Dan yang terakhir Margin Pemasaran di tingkat pedagang pada komoditas Bawang Merah yaitu sebesar Rp. 3.282,Sedangkan Margin untuk Cabe Merah yaitu Rp. 4.000,-. Nilai Persentase Margin pada bulan November 2016 sampai dengan bulan Januari2017 untuk Komoditas Bawang Merah yaitu $7 \%$. Sedangkan untuk komoditas Cabe Merah Besar yaitu $11 \%$. Sedangkan Nilai Efisiensi Pemasaran pada bulan November 2016 sampai dengan bulan Januari 2017, untuk komoditas Bawang Merah pada pelaku usaha Distributor yaitu $86 \%$, untuk pengumpul yaitu 92 $\%$, dan untuk pedagang yaitu $100 \%$. Sedangkan nilai Efisiensi Pemasaran pada bulan November 2016 sampai dengan bulan Januari 2017, untuk komoditas Cabe Merah pada pelaku usaha Distributor yaitu $78 \%$, untuk pengumpul yaitu $87 \%$, dan untuk pedagang yaitu $100 \%$.

2. Stabilitas harga pasar pada komoditas harga Cabe Merah Besardan Bawang Merah harganya tidak stabil dikarenakan harga Cabe Merah Besar dan Bawang merah dari setiap bulannya selalu berubah-ubah sebab dari setiap pelaku usaha menaikkan dasar untuk meningkatkan keuntungan.

\section{DAFTAR PUSTAKA}

Arikunto, Suharsimi. 2002. Metodologi Penelitian. PT. Rineka Cipta. Jakarta.

Arikunto, Suharsimi. 2006. Metodelogi penelitian. Yogyakarta: Bina Aksara.

BPS Sulawesi Barat, 2017

BPS Sulawesi Utara, 2015

Deptan, 2005. Deskripsi Bawang merah varets TukTuk. 20 September 20111 page

Dirjen Holtikultura, 2008.

Elaine B. Johnson; Januari 2007, Contextual teaching \& learning, Cetakan III, Maret2007 Diterbitkan oleh Penerbit MLC Jin.

Hamid Abdul A, dkk 2012. Identifikasi Dan Inventarisasi Usaha Agribisnis di Sekitar Kawasan Hutan Kecamatan Sejangkung Kabupaten Sambas Kalimantan Barat. Kalimantan 
Imran, S. 2008. Analisis faktor-faktor produksi usaha tani cabai rawit, di provinsi Gorontalo. Jurnal Ilmiah Agropolitan.

Nurdin, et al. 2009. Pengembangan Komoditas Unggulan Pertanian Berdasarkan Krakteristik Potensi Sumber daya lahan dan Keunggulan Wilayah untuk Pertanian di Kabupaten Boalemo. Kerjasama Bappeda Kaupaten Boalemo dengan Pusat Kajian Pertanian Tropis Universitas Negri Gorontalo, Tilamuta.

Patong, Dahlan. 2006. Sendi-sendi Pokok Ilmu Usaha Tani. Erlangga, Jakarta

Robbins, S dan Coulter, M. 2007. Manajemen, Edisi Kedelapan, Penerbit PT Indeks: Jakarta.

Roszandi, Dasril. 2011. "Terdesak Bawang Impor, Harga Bawang Merah Lokal Anjlok”. Dalam Tempo ( Maret ). Brebes.

Santika. 2006. Agribisnis Cabai. Penebar Swadaya. Jakarta.183 hlm

Serta Hasil Cabai (Capsicum annuum L.) Sistem Hidroponik. Buletin
Setiadi. 2001. Bertanam Cabai. Penebar Swadaya. Jakarta

Setiawati, Y. 2005. Analisis Varietas dan Polybag Terhadap Pertumbuhan

Sudarmanto. 2009. Bawang Merah. Surakarta : Delta Media.

Sudiyono, A., 2004. Pemasaran Pertanian. UMM Press, Malang.

Sugiarti, S. 2003. Usaha Tani dan Pemasaran Cabe Merah. Jurnal Arta Agrosia: Yogyakarta.

Sunaryono, Hendro H. 2003. Budidaya Cabai Merah. Sianar

Suparyono.2006. Kependudukan dan Kewilayahan. Yudistira. Yogyakarta.

Suratiyah, Ken. 2008. Ilmu Usahatani. Penebar Swadaya. Jakarta.

Swastha. 2002. Manajemen Pemasaran. Edisi Kedua. Cetakan Kedelapan. Jakarta: Penerbit Liberty

Tim Bina Karya Tani. 2008. Pedoman Bertanam Bawang Merah. Bandung: Yrama Widya.

Tulus Tambunan, 2003. Perkembangan Sektor Pertanian di Indonesia, Beberapa Isu Penting. Ghalia Indonesia Jakarta 